\title{
ANALISIS KOHESI DAN KOHERENSI PADA TEKS PROSEDUR, TEKS CERPEN, TEKS LINGKUNGAN DAN KEMUNGKINAN PEMBELAJAAN DI SEKOLAH
}

\section{TUGAS AKHIR SEMESTER}

diajukan untuk memenuhi salah satu persyaratan menyelesaikan tugas perkuliahan Wacana Bahasa Indonesia yang diampu oleh Prof. Dr. Syahrul Ramadhan, M.Pd.

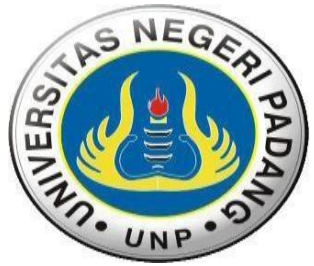

NADIRA HARIKA

NIM 17016114/2017

NO URUT 14

PROGRAM STUDI PENDIDIKAN BAHASA INDONESIA

JURUSAN BAHASA DAN SASTRA INDONESIA DAN DAERAH

FAKULTAS BAHASA DAN SENI

UNIVERSITAS NEGERI PADANG 


\section{KATA PENGANTAR}

Puji syukur penulis haturkan ke hadirat Allah swt yang telah memberikan rahmat dan hidayah-Nya sehingga saya dapat menyelesaikan tugas makalah yang berjudul Analisis Kohesi dan Koherensi pada Teks Prosedur, Teks Cerpen, Teks Lingkungan dan Kemungkinan Pembelajaan di Sekolah ini tepat pada waktunya.

Adapun tujuan dari penulisan dari makalah ini adalah untuk memenuhi tugas Prof. Dr. Syahrul Ramadhan, M.Pd pada mata kuliah Wacana Bahasa Indonesia. Selain itu, makalah ini juga bertujuan untuk menambah wawasan tentang kohesi dan koherensi pada teks prosedur, teks cerpen, teks lingkungan dan kemungkinan pembelajaan di sekolah bagi para pembaca dan juga bagi penulis.

Saya mengucapkan terima kasih kepada Prof. Dr. Syahrul Ramadhan, M.Pd, selaku dosen mata kuliah Wacana Bahasa Indonesia yang telah memberikan tugas ini sehingga dapat menambah pengetahuan dan wawasan sesuai dengan bidang studi yang saya tekuni.

Saya juga mengucapkan terima kasih kepada semua pihak yang telah membagi sebagian pengetahuannya sehingga saya dapat menyelesaikan makalah ini.

Saya menyadari, makalah yang saya tulis ini masih jauh dari kata sempurna. Oleh karena itu, kritik dan saran yang membangun akan saya nantikan demi kesempurnaan makalah ini.

Padang, 1 Juni 2020

Nadira Harika

NIM 17016114/2017 


\section{DAFTAR ISI}

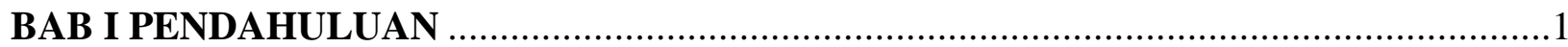

A. Latar Belakang ............................................................................................. 1

B. Rumusan Masalah .....................................................................................

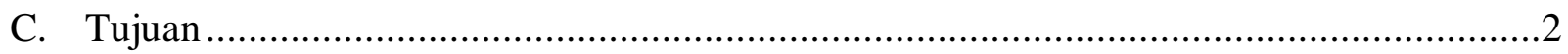

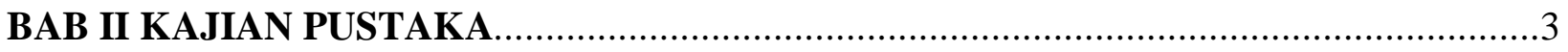

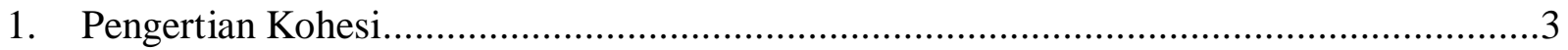

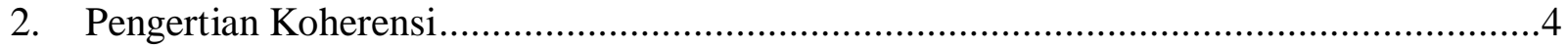

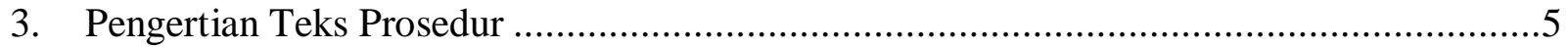

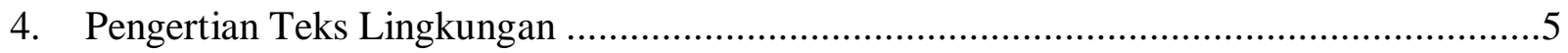

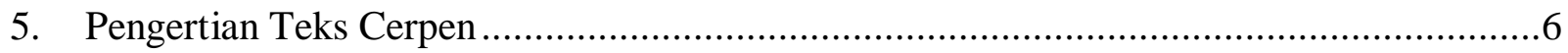

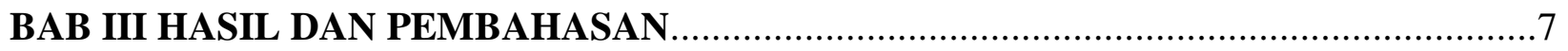

A. Analisis Kohesi dan Koherensi dalam Teks Prosedur “3 Cara Membuat Donat Goreng yang Lembut, Empuk dan Mengembang". ............................................................

B. Analisis Kohesi dan Koherensi dalam Teks Lingkungan "Lingkungan Hidup Hanya Menjadi Sebuah Pembahasan Bukan Pekerjaan"'.....................................................8

C. Analisis Kohesi dan Koherensi dalam Teks Cerpen "Rembulan di Mata Ibu" Karya Asma

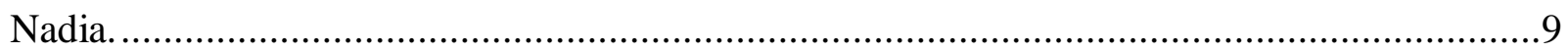

D. Kemungkinan Pembelajaran Ketiga Wacana tersebut di Sekolah. ...............................10

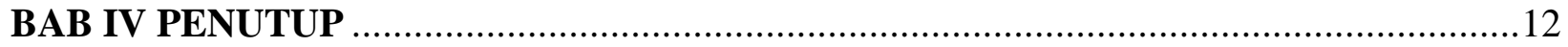

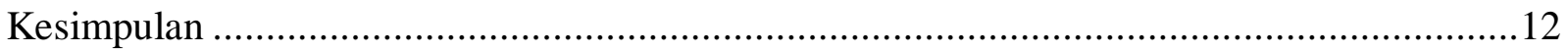

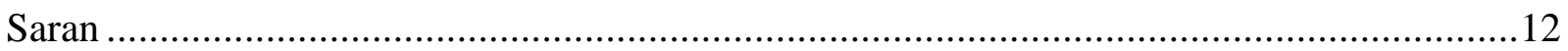

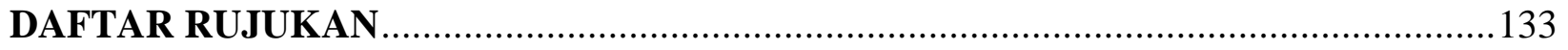




\section{BAB I \\ PENDAHULUAN}

\section{A. Latar Belakang}

Wacana yang baik adalah wacana yang harus memperhatikan hubungan antarkalimat, sehingga dapat memelihara keterkaitan dan keruntutan antarkalimat. Wacana dikatakan lengkap karena didalamnya terdapat konsep, gagasan, pikiran, atau ide yang utuh, yang bisa dipahami oleh pembaca (wacana tulis) atau oleh pendengar (wacana lisan) tanpa keraguan apa pun. Wacana dikatakan tertinggi atau terbesar karena wacana dibentuk dari kalimat atau kalimat-kalimat yang memenuhi persyaratan gramatikal dan persyaratan kewacanaan lainnya (kohesi dan koherensi). Sejalan dengan pandangan Sumarlam bahwa bahasa itu terdiri atas bentuk dan makna, hubungan dalam wacana dapat dibedakan menjadi dua jenis yaitu hubungan bentuk yang disebut kohesi dan hubungan makna atau hubungan semantis yang disebut koherensi (dalam Nurfitriani, et.al, 2018). Selain itu menurut Djajasudarma (dalam Winita, 2019) kohesi merupakan keserasian hubungan unsur-unsur dalam wacana sedangkan koherensi merupakan kepaduan wacana sehingga membawa ide tertentu yang dipahami khalayak.

Analisis kohesi dan koherensi ini disusun karena mengingat kohesi pada dasarnya bertujuan untuk mendapatkan efek intensitas makna bahasa, kejelasan informasi, dan keindahan bahasa. Pada kondisi tertentu unsur-unsur kohesi menjadi penting bagi terbentuknya wacana yang koheren. Analisis pemakaian koherensi bertujuan agar terciptanya susunan dan struktur wacana yang memiliki sifat serasi runtut dan logis. Karena suatu rangkaian kalimat yang tidak memiliki hubungan bentuk dan makna secara logis, tidak dapat dikatakan sebagai wacana.

Mulyana (dalam Wicaksono, 2019) menyatakan bahwa suatu wacana dituntut memiliki keutuhan struktur. Keutuhan ini dibangun oleh komponen-komponen yang terjalin dalam suatu organisasi kewacanaan yang disebut struktur wacana. Aspek-aspek yang mempengaruhi keutuhan wacana itu adalah kohesi dan koherensi. Pernyataan tersebut menunjukkan bahwa kohesi dan koherensi sangat erat kaitannya dengan bidang analisis wacana. Kohesi dan koherensi berhubungan dengan konsep wacana, yaitu sebagai unsur pembentuk wacana yang ditandai dengan penanda kohesi dan penanda koherensi. Kohesi 
merupakan hubungan antar bagian dalam wacana yang ditandai dengan alat penggunaan unsur bahasa. Sebuah wacana dapat dikatakan kohesif jika dilengkapi dengan koherensi. Kohesi dan koherensi memiliki hubungan erat, sehingga dapat menghasilkan sebuah wacana dengan kesatuan makna yang utuh. Martutik (dalam Saputra, 2016) menyatakan bahwa penggunaan penanda kohesi merupakan bagian yang penting dalam membentuk wacana yang utuh dan koheren. Penanda-penanda kohesi itu dapat menyatakan hubungan.

Penelitian ini bertujuan untuk mendeskripsikan bentuk kohesi dan koherensi yang terdapat dalam wacana/teks prosedur, teks lingkungan, teks cerpen dan kemungkinan pembelajaran ketiga wacana tersebut di sekolah.

\section{B. Rumusan Masalah}

1. Bagaimana analisis kohesi dan koherensi dalam teks prosedur?

2. Bagaimana analisis kohesi dan koherensi dalam teks lingkungan?

3. Bagaimana analisis kohesi dan koherensi dalam teks cerpen?

4. Bagaimana kemungkinan pembelajaran ketiga wacana tersebut di sekolah?

\section{Tujuan}

1. Untuk mendeskripsikan analisis kohesi dan koherensi dalam teks prosedur.

2. Untuk mendeskripsikan analisis kohesi dan koherensi dalam teks lingkungan.

3. Untuk mendeskripsikan analisis kohesi dan koherensi dalam teks cerpen.

4. Untuk mendeskripsikan kemungkinan pembelajaran ketiga wacana tersebut di sekolah. 


\section{BAB II \\ KAJIAN PUSTAKA}

\section{Pengertian Kohesi}

Sebuah tulisan dapat dikatakan mudah dibaca dan dipahami bila memiliki kerapian bentuk dan kepaduan makna. Tarigan memberi definisi kohesi sebagai berikut: Kohesi merupakan aspek bentuk yang mengacu kepada aspek formal bahasa yakni bagaimana proposisi-proposisi berhubungan satu sama lainnya untuk membentuk suatu teks (Hanafiah, 2014). Artinya kohesi merupakan organisasi sintaktik dimana kalimat-kalimat disusun secara terpadu untuk menghasilkan wacana, baik dari segi tingkat gramatikal maupun tingkat leksikal tertentu. Sementara Halliday dan Hasan (dalam Prayudha, 2016) mengatakan kohesi memungkinkan terjalinnya keteraturan hubungan semantik antar unsur-unsur dalam wacana. Artinya kohesi juga merupakan organisasi semantik, yang merujuk kepada perkaitan kebahasaan yang didapati pada suatu ujaran yang membentuk wacana. Lebih jauh Halliday dan Hasan membagi kohesi makna menjadi dua bagian yakni secara gramatikal dan leksikal yang harus memilki keterpaduan yang terdapat dalam suatu kesatuan teks. Sejalan dengan pendapat Halliday dan Hasan, Richards berpendapat bahwa kohesi merupakan hubungan gramatikal dan leksikal antara berbagai unsur yang berbeda dalam satu teks yang dapat berbentuk hubungan antara kalimat ang berbeda atau yang berbeda dalam satu kalimat (Prayudha, 2016).

Dengan demikian kohesi adalah salah satu standar yang menandai bahwa sebuah teks atau wacana itu dianggap komunikatif, tanpa kohesi teks atau wacana tidak dianggap komuikatif. Sebagaimana telah disebutkan di atas bahwa Halliday dan Hasan (Prayudha, 2016) membagi kohesi kepada dua jenis, yakni kohesi gramatikal dan kohesi leksikal. Kohesi gramatikal merupakan segi bentuk atau struktur lahir wacana yang mencakup kohesi pengacuan atau referen (reference), kohesi penggantian atau substitusi (substitution), kohesi pelesapan (ellipsis), dan hubungan atau perangkaian (conjunction).

Referen (reference) atau pengacuan adalah satuan lingual tertentu yang mengacu pada satuan lingual lainnya baik yang di depan maupun yang di belakang. Menurut Achmad aspek leksikal adalah kata atau frasa yang menghubungkan kalimat-kalimat dengan pemarka leksikal dan dapat membentuk suatu wacana yang utuh. Sependapat 
dengan Halliday, Achmad mengatakan bahwa aspek leksikal dapat diwujudkan dengan reiterasi dan kolokasi. Reiterasi atau pengulangan digunakan untuk mengulang suatu preposisi atau bagian dari preposisi untuk menciptakan hubungan kohesif. Reiterasi dirinci menjadi; 1) Repetisi yakni pengulangan satuan lingual (bunyi, suku kata, kata atau bagian kalimat) yang dianggap penting untuk memberi tekanan dalam sebuah konteks yang sesuai, 2) Sinonim secara semantik mengandung makna istilah atau ungkapan (kata, frasa, atau kalimat) yang maknanya kurang lebih sama dengan makna ungkapan lain, 3) Hiponim secara adalah kata atau frasa yang maknanya termasuk dalam makna kata atau frasa lain. 4) Metonim bagian dari pengulangan yang bermakna sebutan bagi orang, benda, tempat atau nama tertentu yang dianggap popular dan dekat dengan masyarakat, 5) Antonim adalah nama lain untuk benda atau hal lain yang maknanya berlawanan, beroposisi dengan kata atau frasa lain dapat digunakan untuk menghubungkan kalimat yang satu dengan kalimat yang lain di dalam suatu tuturan (Hanafiah, 2014). Aspek leksikal berikutnya ialah kolokasi. Kolokasi artinya makna yang sama yang ada dalam lingkungan yang sama. Semua hal yang selalu berdekatan dengan yang lain biasanya diasosiasikan membentuk suatu kesatuan. Kolokasi dirinci menjadi: 1) Kolokasi penuh yakni pengulangan kata atau frasa pada kalimat sebelumnya yang ada dalam lingkungan yang sama, 2) Ekuivalensi yakni hubungan pengulangan pada kalimat sebelumnya dengan kalimat sesudahnya yang sebanding atau sepadan.

\section{Pengertian Koherensi}

Koherensi menurut Tarigan adalah aspek makna yang mengacu pada aspek ujaran atau yang menggambarkan bagaimana proposisi-proposisi yang tersirat dapat ditafsirkan dan disimpulkan dan menurut Renkema koherensi adalah jalinan antar bagian dalam wacana; kepaduan semantis yang dapat dicapai oleh faktor-faktor di luar wacana (Aisiyah, 2015). Jadi koherensi adalah kesinambungan informasi. Menurut Keraf (dalam Amin, 2016) koherensi adalah keserasian hubungan timbal balik antar unsur-unsur dalam kalimat serta kekompakan hubungan kalimat-kalimat dalam wacana. Beaugrande dan Dressler (dalam Amin, 2016) mengatakan “... coherence concerns the way in which components of the textual words; the configuration of concepts and relations which underlie the surface text are mutually accessible and relevant". 
Jadi koherensi mengacu pada bagaimana komponen tekstual, seperti konfigurasi konsep dan hubungan yang mendasari sebuah teks saling berterima dan berkaitan. Dengan kata lain koherensi adalah pemahaman tentang makna yang dimilki oleh pendengar atau pembaca.

\section{Pengertian Teks Prosedur}

Teks prosedur merupakan suatu langkah-langkah dan tujuan yang harus diikuti agar suatu pekerjaan dapat dilakukan. Teks prosedur memiliki manfaat yang besar dalam kehidupan. Teks prosedur membantu mengetahui cara-cara melakukan aktifitas tertentu dan kebiasaan hidup yang benar. Selain itu, membantu dalam menggunakan alat dengan benar tanpa membahayakan diri dan tanpa merusak alat itu sendiri. Untuk mencapai tujuan yang tepat teks prosedur harus disusun sesuai dengan urutan yang benar. Karena langkahlangkah dalam menyusun teks prosedur tidak dapat dibalik-balik untuk mencapai tujuan tersebut.

Pradana (Arviyana, et.al, 2017) mengatakan bahwa pelajaran menulis teks prosedur menjadi penting karena setiap peserta didik mampu memahami dan mengutarakan idenya. Apabila ide tersebut diutarakan secara sistematis dan terperinci pelajaran bahasa Indonesia di sekolah-sekolah yang memasukkan teks prosedur sebagai salah satu materi yang dianggap penting dapat dipahami oleh siswa.

\section{Pengertian Teks Lingkungan}

Pendidikan lingkungan adalah upaya bersama yang secara sadar diatur untuk mengajarkan atau menarik perhatian manusia tentang bagaimana fungsi lingkungan alam dan bagaimana manusia ini dapat mengelola dan melindunginya . Pendidikan ini terjadi dalam praktik mencari kreativitas dan penemuan, dan eksplorasi realitas tanpa menyadarinya. Mengembangkan pengetahuan tentang signifikansi ilmiah dan sosial dari lingkungan adalah langkah pertama dalam pembentukan masyarakat yang ramah lingkungan. Melalui pengetahuan dan kesadaran, nilai-nilai dan sikap positif muncul yang akan mendorong tindakan untuk melakukan penyesuaian dengan gaya hidup dan kebiasaan konsumsi yang akan mengurangi beban yang kita tempatkan pada lingkungan. Tujuan dari pendidikan lingkungan adalah untuk membuat siswa berpartisipasi dalam melindungi lingkungan. Agar siswa untuk berpartisipasi dalam melindungi lingkungan, penting untuk mengembangkan pengetahuan tentang lingkungan, kesadaran lingkungan dan perubahan 
perilaku terhadap lingkungan. Individu harus didorong untuk tidak memandang lingkungan sebagai sesuatu yang harus dieksploitasi untuk tujuan mereka, tetapi sebagai aset berharga yang layak dilindungi untuk kelangsungan hidup manusia. (Ramadhan, et.al, 2019).

Pendidikan lingkungan dapat diintegrasikan ke dalam pelajaran lain, salah satunya adalah pembelajaran bahasa. integrasi dapat dilakukan dengan menggunakan tema tentang lingkungan dalam pembelajaran teks. Melalui teks yang dipelajari, siswa dapat belajar bahasa dan mendapatkan pengetahuan lingkungan melalui isi teks yang sedang dibaca.

\section{Pengertian Teks Cerpen}

Cerita Pendek (Cerpen) dalam bahasa Inggris dikenal dengan short story, merupakan satu karya sastra yang sering kita jumpai di berbagai media massa. Namun demikian, apa sebenarnya dan bagaimana ciri-ciri cerita pendek itu banyak yang masih memahaminya. Cerita pendek adalah karangan nasihat yang bersifat fiktif yang menceritakan suatu peristiwa dalam kehidupan pelakunya relatif singkat tetapi padat.

Pembelajaran sastra ditujukan untuk meningkatkan kemampuan siswa dalam menikmati, menghayati, dan memahami karya sastra serta mengambil hikmah atas nilainilai luhur yang terselubung di dalamnya. (Sukma, 2007). Karya sastra dapat membukakan mata pembaca untuk mengetahui realitas sosial, politik dan budaya dalam rangka pembinaan moral dan estetika. (Sukma, 2007)

Melalui tahapan poses menulis, siswa diajak dan diarahkan untuk menemukan halhal yang dipikirkannya. Hal-hal yang dipikirkan siswa tidak lepas dari pengalaman dan pengetahuan yang dimilikinya. Tahapan-tahapan yang bermula dari pemunculan gagasan sampai menjadi suatu karya disebut dengan proses menulis kreatif. Menulis cerpen termasuk ke dalam menulis kreatif. (Sukma, 2017).

Wacana tulis adalah wacana yang disampaikan secara tertulis dan mengandung komunikasi tidak langsung contohnya cerpen, teks prosedur dan teks lingkunga dan lainlain. Pembahasan kali ini akan mengkaji tentang analisis wacana tulis berupa teks prosedur, teks cerpen, teks lingkungan. 


\section{BAB III}

\section{HASIL DAN PEMBAHASAN}

\section{A. Analisis Kohesi dan Koherensi dalam Teks Prosedur "3 Cara Membuat Donat Goreng yang Lembut, Empuk dan Mengembang”.}

1. Kohesi

a) Kohesi Gramatikal

- Referensi (Pengacuan Kata)

1) ... bentuknya yang unik membuat kue ini memiliki banyak penggemar.

2) Selain itu cara membuat donat goreng...

3) berikut ini cara membuat donat goreng yang lembut dan empuk.

4) Variasi cara membuat donat goreng ini juga agar tak bosan.

5) Donat goreng satu ini teksturnya padat dan empuk dengan topping

- Substitusi (Penggantian Kata)

1) tekstur empuk serta bentuknya

- Elipsis (Pelesapan Kata)

1) Donat dibuat menggunakan adonan roti. Untuk mendapatkan tekstur $\varnothing$ yang lembut diperlukan gluten

2) Cara membuat donat sendiri ada 3 metode, di antaranya $\varnothing$ goreng, $\varnothing$ panggang menggunakan oven, dan Ø kukus

3) Tutupi adonan menggunakan kain dan diamkan di tempat hangat suhu ruang selama 15 menit. Setelah 15 menit, $\varnothing$ mengembang. Tinju-tinju $\varnothing$ untuk mengeluarkan udara.

4) Letakkan adonan yang telah terbentuk dengan diberi jarak pada wadah datar. Tutupi $\varnothing$ dengan kain dan diamkan selama 30 menit.

- Konjungsi (Perangkaian Kata)

1) Makanan berbentuk bundar dan umumnya bolong

2) Campur tepung terigu, gula, dan mipan. Lalu masukkan telur.

3) donat berukuran kecil, atau gunakan cetakan

4) berwarna kuning agak kecoklatan kemudian balik permukaan

2. Koherensi

Ditemukan penggunaan kata, frasa, klausa dan kalimat sebagai berikut ini :

1) Pasalnya cara membuat donat goreng dinilai lebih mudah dan bisa dilakukan di rumah meski dengan peralatan seadanya. Selain itu cara membuat donat goreng bisa menghasilkan donat dengan tektur lebih lembut dan empuk.

2) Diamkan adonan donat selama 30-45 menit hingga adonan mengembang. Setelah mengembang, kempeskan adonan. 


\section{B. Analisis Kohesi dan Koherensi dalam Teks Lingkungan "Lingkungan Hidup Hanya Menjadi Sebuah Pembahasan Bukan Pekerjaan”.}

1. Kohesi

a) Kohesi Gramatikal

- Referensi (Pengacuan Kata)

1) Tahukan kamu? Tanggal 10 Januari diperingati sebagai Hari Lingkungan Hidup Indonesia. Sudahkah kamu mencintai lingkungan dan turut menjaganya?

2) Kerusakan lingkungan ini salah satunya diakibatkan oleh operasi pertambangan yang masif di Kalimantan timur.

3) mengingatkan kepada kita semua tentang beberapa hal atau banyak hal pula...

- Substitusi (Penggantian Kata)

1) mencintai lingkungan dan turut menjaganya?

2) mengarahkan rakyatnya tentang pengelolaan.

3) ketidakmampuan mereka menangani permasalahan.

- Elipsis (Pelesapan Kata)

1) menjaga kelestarian lingkungan hidup, menjamin keberlangsungan hidup Ø termasuk satwa dan manusia.

2) Kalimantan Timur tengah mengalami gelombang pengrusakan lingkungan hidup. Kerusakan $\varnothing$ ini salah satunya diakibatkan oleh operasi pertambangan yang masif di Kalimantan timur.

3) sistem pendidikan kita harus diakui dan diterima dengan lapang dada. Perbaikan $\varnothing$ mesti diarahkan kepada capaian mata pelajaran dan atau mata kuliah di sekolah.

- Konjungsi (Perangkaian Kata)

1) hak penglolaan secara berkelanjutan dan bijaksana, menjaga kelestarian lingkungan hidup

2) Pemerintah harus melakukan penanaman pohon kembali, hingga merestorasi ekosistem hutan bakau dan gambut

3) maupun nasional, sebenarnya berakar dari perilaku manusia

4) lurah atau kepala desa

5) Banyak penyebabnya tetapi yang paling dominan adalah ketidakmampuan

6) Diikuti oleh sulitnya air bersih lalu, kerusakan hutan ada diperingkat ke delapan

2. Koherensi

7) sekolah rendah sampai ke perguruan tinggi

Ditemukan penggunaan kata, frasa, klausa dan kalimat sebagai berikut ini : 
1) Negara juga semakin aktif membuat perjanjian dan peraturan antar negara untuk mengatasi berbagai permasalahan yang ada. Namun, apa saja masalah lingkungan hidup yang kita hadapi saat ini?

2) Pembangunan infrastruktur menjadi salah satu langkah yang diambil pemerintah untuk melakukan percepatan dan perluasan pembangunan ekonomi Indonesia. Meski demikian, tanpa rumusan kebijakan yang berwawasan lingkungan, pembangunan akan membawa dampak buruk pada kualitas lingkungan hidup.

\section{Analisis Kohesi dan Koherensi dalam Teks Cerpen "Rembulan di Mata Ibu" Karya}

\section{Asma Nadia.}

1. Kohesi

a) Kohesi Gramatikal

- Referensi (Pengacuan Kata)

1) "kau pikir bicara bisa membuatmu mendapatkan uang?"

2) "beginilah jadinya kalau anak perempuan Cuma bisa belajar. Tak tahu bagaimana memasak! Siapa yang mau menikahimu nanti kalau begini Diah?"

3) "Kau tak kan berhasil Diah! Tak usah capek-capek! Wanita akan kembali ke dapur, apapun kedudukannya!"

4) "ada apa? Tulisanmu ada yang ditolak? Mana mungkin!"

5) "Li ... percayakah kamu kalau aku bilang, ada Ibu yang tak pernah mencintai anaknya?".

6) "Aku rasa, mencintai adalah naluri yang muncul otomatis saat seseorang menjadi Ibu, Diah!

7) "Diah ... kenapa kamu menanyakan itu?

8) "Ibuku sakit Li! Apa yang harus kulakukan?"

9) "Itu aja kok, bingung! Barangkali dia kangen padamu. Tengoklah Ibu, Di! Eh, kapan terakhir kali bertemu?"

10) "Aku tak pernah pulang, Laili. Sudah lima tahun!"

- Substitusi (Penggantian Kata)

1) "ku rasa, mencintai adalah naluri yang muncul otomatis saat seseorang menjadi Ibu, Diah! Itu karunia Allah yang diberikan pada setiap Ibu. Rasa kasih, mengayomi, dan melindungi!"

2) "Tapi kau harus menerimanya Diah, itu uangmu. Uang yang kirimkan selama ini untuk Ibu lewat mbakmu. Sebagian ada juga hakmu dari penjualan ternak,"

3) "Kau akan membutuhkannya Diah, untuk pernikahanmu nanti. Semua mbakmu hidup sederhana. Anak mereka banyak, mungkin tak kan banyak bisa membantumu jika hari itu tiba!"

- Elipsis (Pelesapan Kata)

1) "Jadi perempuan jangan terlalu sering melamun Diah! Bekerja $\varnothing$, itu akan membuat tubuhmu kuat!"

- Konjungsi (Perangkaian Kata) 
1) "Jangan coba membantah! Kurang baik dan terpelajar apa si Retno? Lalu Sumirah? Bahkan anak pak Haji Tarjo? Pulang-pulang malah jadi perempuan jalang! Aku tak ingin punya anak jalang!"

\section{Koherensi}

Ditemukan penggunaan kata, frasa, klausa dan kalimat sebagai berikut ini :

1) "Hey... jangan begitu dong, Di! selama ini kamu selalu repot-repot saat mengunjungi kami. Jadi.. biarkan aku yang mengurus perjalananmu kali ini. Lagi pula, kamu masih harus mempersiapkan presentasi skripsimu, kan?"

2) "Sebetulnya Ibu sangat kangen kepadamu Diah, tapi Ibu lebih mementingkan kuliahmu."

3) "Jangan coba membantah! Kurang baik dan terpelajar apa si Retno? Lalu Sumirah?

4) "Ibu tahu.. Ibu baca surat yang kirimkan kepada mbak-mbakmu.. tapi itu uangmu. Kau membutuhkannnya. Mungkin tak lama lagi."

5) "Ibu tak butuh uang sebanyak itu, Diah! Lagi pula.. Ibu khawatir tak bisa lagi memberimu uang."

\section{Kemungkinan Pembelajaran Ketiga Wacana tersebut di Sekolah.}

Menulis merupakan suatu keterampilan berbahasa yang dibutuhkan untuk meningkatkan kualitas pembelajaran dan sebuah kegiatan yang menyusun hasil pikiran, ide, atau gagasan dengan menggunakan rangkaian kata-kata terpadu dalam bahasa tulis (Jaya, et.al, 2013). Kerampilan menulis ialah keterampilan yang paling penting dipelajari segala bahasa (Yantama, et.al, 2013) dan dengan penguasaan keterampilan menulis, diharapkan siswa dapat mengungkapkan gagasan, pikiran, dan perasaan yang dimilikinya setelah menjalani proses pembelajaran dalam berbagai jenis tulisan, baik fiksi maupun nonfiksi. Sejalan dengan pendapat Maybury (dalam Sukma, 2007) dengan adanya kegiatan menulis teks siswa dapat menuangkan semua gagasan, perasaan, harapan, dan imajinasi yang dimilikinya ke dalam bentuk tulisan. Selain itu keterampilan menulis salah satu keterampilan yang paling berperan penting dalam kehidupan ( Arviyana, et.al, 2017) karena Kegiatan menulis membuat siswa dapat mengembangkan gagasan, mengungkapkan sesuatu, dan membiasakan bernalar (Rahmatina \& Sukma, 2015). Selanjutnya Menurut Siswatini (dalam Fitrianita, et.al, 2017), menulis adalah menyusun kata-kata menjadi kalimat dengan memperhatikan kaidah tata bahasa untuk menyampaikan pengetahuan atau mengimformasikan sesuatu. Dengan demikian, segala informasi, ilmu pengetahuan, dan berbagai kecakapan yang diperoleh siswa dalam pembelajaran tidak akan sekadar menjadi 
hafalan yang mudah dilupakan sesaat setelah siswa menjalani tes tetapi menambah pengetahuan siswa mengenai sebuah wacana.

Pembelajaran menulis wacana adalah suatu aktivitas intruksional yang pada dasarnya telah diajarkan dalam pendidikan formal dari jenjang SD, SMP, dan SMA. Pembelajaran menulis wacana pada SD merupakan pembelajaran dasar, kemudian pada jenjang SMP pembelajaran menulis wacana diajarkan untuk melatih kemampuan siswa dalam menulis wacana. Selanjutnya pada jenjang SMA pembelajaran menulis wacana diarahkan agar siswa mampu dan terampil dalam menulis wacana baik dari segi pemakaian bahasa maupun cara penulisannya. Kegiatan menulis dapat meningkatkan keterampilan berbahasa (Putri, et.al, 2018). Oleh karena itu, keterampilan menulis harus dimiliki siswa mulai dari tingkat Sekolah Dasar kemudian pada jenang selanjutnya (Amelia, et.al, 2015).

Melalui penulisan wacana teks prosedur, teks lingkungan, teks cerpen siswa dilatih berpikir untuk mengembangkan ide atau gagasan dan perasaan kemudian dituangkan ke dalam tulisan. Tujuan pembelajaran tersebut untuk menjadikan siswa terampil dalam menulis wacana yang merupakan wujud komunikasi tulisan. Melalui kegiatan menulis wacana siswa dapat menuangkan ide atau gagasan, dan perasaan dalam bentuk tulisan yangdikomunikasikan kepada pembaca. 


\section{BAB IV}

\section{PENUTUP}

\section{Kesimpulan}

Kohesi merupakan aspek formal bahasa dalam wacana (hubungan yang tampak pada bentuk). Sedangkan koherensi merupakan hubungan perkaitan antarproposisi, tetapi perkaitan tersebut tidak secara eksplisit atau nyata dapat dilihat pada kalimat-kalimat yang mengungkapkannya. Pada data yang telah dianalisis oleh penulis dapat disimpulkan bahwa pada setiap paragraf dan kalimat dari data yang dianalisis terdapat unsur yang menunjukan bahwa wacana tersebut kohesif dan koheren. Itu ditandai oleh beberapa tanda yang memang tanda itu menunjukan sifat yang koheren dan kohesif.

\section{Saran}

Dalam makalah ini tentu saja tidak terhindar dari kesalahan dan kekeliruan yang lazim dilakukan oleh penyusun. Maka dari itu kritik dan saran yang membangun sangat kami butuhkan untuk memperbaiki penyusunan makalah ini. Terimakasih. 


\section{DAFTAR RUJUKAN}

Aisyah, N. (2019). Analisis Kohesi dan Koherensi Wacana pada Lembar Kerja Siswa Bahasa Indonesia untuk SMA/ MA/ SMK. MAK Kelas XI. Jurnal Ilmu Pendidikan Bahasa dan Sastra Indonesia, 4(3), p 151-160.

Amelia, R., Sukma, E., dan Asma, N. (2015). Pembelajaran Menulis Laporan Percobaan dengan Pendekatan Saintifik di Sekolah Dasar. Prosiding Seminar Nasional Jurusan PGSD FIP UNP, 1(1), p 1-8.

Amin, M., Syamsudin., dan Zulianto, S. (2016). Kohesi dan Koherensi dalam Artikel Ilmiah Populer Radar Sulteng. Bahasantodea, 4(3), p 48-56.

Arviyana, M., Syahrul., dan Tressyalina. (2017). Pengaruh Model Discovery Learning Berbantuan Media Audiovisual terhadap Keterampilan Menulis Teks Prosedur Siswa Kelas VII SMP Negeri 12 Padang. Jurnal Pendidikan Bahasa dan Sastra Indonesia, Vol 6.(2), p 183-191.

Fitrianita, D., Syahrul. R., dan Tressyalina. (2017). Korelasi Keterampilan Memahami Teks Deskripsi dengan Keterampilan Menulis Teks Deskripsi Siswa Kelas VII SMP Negeri 15 Padang. Jurnal Pendidikan Bahasa dan Sastra Indonesia, 6(2), p 102-108.

Hanafiah, W. (2014). Analisis Kohesi dan Koherensi pada Wacana Buletin Jumat. Epigram, 11(2), p 135-152.

Jaya, S., Syahrul, R., dan Ermanto. (2013). Peningkatan Keterampilan Menulis Puisi Melalui Media Gambar Siswa Kelas X.1 SMA Negeri 2 Kota Sungai Penuh. Jurnal Bahasa, Sastra dan Pembelajaran, 1 (2), p 88-95.

Mustawan, A. (2020). Lingkungan Hidup Hanya Menjadi Sebuah Pembahasan Bukan Pekerjaan. Online. $\quad$ https://kuninganmass.com/anything/netizen-mass/lingkungan-hidup-hanyamenjadi-sebuah-pembahasan-bukan-pekerjaan/. Diunduh 1 Juni 2020.

Nurfitriani, Rajab B., Azwardi. (2018). Analisis Kohesi dan Koherensi dalam Proposal Mahasiswa PBSI Tanggal 23 Desember 2014. Jurnal Bahasa dan Sastra Vol 12 No 1, p 42.

Prayudha. (2016). The Cohesion and Coherence of the Editorials in the Jakarta Post. Ahmad Dahlan Journal of English Studies. Vol 3 Issue 2, p 32-36.

Putri, N., Syahrul, R., dan Afnita. (2018). Pengaruh Penggunaan Model Discovery Learning Berbantuan Media Audiovisual terhadap Keterampilan Menulis Teks Biografi Siswa 
Kelas X SMA Negeri 12 Padang. Jurnal Pendidikan Bahasa dan Sastra Indonesia, 7(3), p 192-198.

Rahmatina., dan Sukma, E. (2015). Peningkatan Keterampilan Menulis Deskripsi dengan Menggunakan Strategi Mind Map di Sekolah Dasar. Prosiding Seminar Nasional Jurusan PGSD FIP UNP, 1 (1), p 1-8.

Ramadhan, S., Elfia S., V Indriyani. (2019). The 1st International Conference on Environmental Sciences (ICES2018) IOP Publishing, p 2.

Saputra, G. A. W. (2016). Analisis Peranti Kohesi pada Teks Eksposisi Siswa Kelas X Akomodasi Perhotelan 1 SMK PGRI 2 Gianyar Tahun Pelajaran 2014/2015. Jurnal Linguistika Vol 23 No 45 p 160.

Shidqiyyah, S. (2018). 3 Cara Membuat Donat Goreng yang Lembut, Empuk dan Mengembang Online. https://www.liputan6.com/lifestyle/read/3686418/3-cara-membuat-donat-gorengyang-lembut-empuk-dan-mengembang. Diunduh 1 Juni 2020.

Suci, A. M. (2014). Rembulan di Mata Ibu" Karya Asma Nadia. Online. https://arummelatisuci.blogspot.com/2014/04/cerpen-rembulan-di-mata-ibu.html. Diunduh 1 Juni 2020.

Sukma, E. (2007). Peningkatan Kemampuan Menulis Puisi Siswa Kelas V SD Negeri Sumbersari III Malang dengan Strategi Pemetaan Pikiran. Diksi, 14(1), p 38-47.

Sukma, E., Mahjuddin, R., Amelia, R. (2017). Literacy Media Development in Improving Reading and Writing Skill of Early Class Students in Elementary School Padang Utara Padang. Advances in Social Science, Education and Humanities Research, 118(9), p 145-150.

Syofiani,. Zaim, M., Syahrul, R., dan Agustina. (2018). Peningkatan Keterampilan Berbahasa Siswa melalui Pemanfaatan Media Teka-Teki Silang: Menciptakan Kelas yang Menyenangkan. Jurnal Ta'dib, 21(2), p 87-97.

Wicaksono, A. (2019). Analisis Wacana Kritis Iklan Operator Seluler (Teks dan Konteks Iklan XL dengan Kartu AS). Jurnal Ksatra Vol 1 No 1, p 2.

Winita, S., Syahrul R.(2019). Kohesi Gramatikal Referensi dalam Koleksi Cerita Pendek Kompas. Jurnal Pendidikan Bahasa dan Sastra, Vol 19 No 2, p 221

Yantama, S. P., Syahrul, R., dan Afnita. (2013). Penerapan Pembelajaran Berbasis Masalah dalam Pembelajaran Teks Puis untuk Siswa Kelas VIII SMP Negeri 4 Sungai Penuh. Jurnal Pendidikan Bahasa dan Sastra Indonesia, 1(3), p 104-114. 